\title{
"Partida do Audaz Navegante", de Guimarães Rosa: Ressonâncias ODISSEICAS, EM CLAVE MINIMALISTA
}

Adélia Bezerra de Meneses

Universidade de São Paulo/Universidade de Campinas

\section{Resumo}

A proposta é estudar a reapropriação, em clave minimalista, que Guimarães Rosa faz desse "capital cultural" que é a Odisseia, abordada aqui enquanto matriz do romance de aventuras e do romance de amor. Flagra-se um processo de estilização, miniaturização, estranhamento e carnavalização em "Partida do Audaz Navegante", conto que fornece a oportunidade para uma reflexão sobre a arte enquanto sucedâneo do brincar infantil, bem como para o tratamento de questões fundamentais: a relação entre literatura e vida, a eficácia psíquica do narrar, a vida enquanto travessia (vita/via), desejo x necessidade, encontro dos contrários. Além disso, procede-se a um contraponto com Fernando Pessoa e com Caetano Veloso (“Os Argonautas").

\section{Abstract}

The text seeks to study the reappropriation of the "cultural capital" of the Odyssey-taken here as matrix both of the adventure novel and of the romance novel-performed, in a minimalist key, by Guimarães Rosa. What is discovered is a process of stylization, miniaturization, estrangement and carnivalization in "Partida do Audaz Navegante", short story that elicits a reflection on art as a continuation of child's play, as well as treatment of fundamental questions: the relation between literature and life, the psychic efficacy of narration, life as voyage (vita/via), desire X necessity, the meeting of opposites. Furthermore, the paper establishes counterpoints with Fernando Pessoa and Caetano Veloso.

\section{Palavras-chave}

João Guimarães Rosa, Odisseia, "Partida do Audaz Navegante".

\section{Keywords}

João Guimarães Rosa, Odyssey

"Partida do Audaz Navegante". 
Além das possíveis ressonâncias odisseicas, o conto "Partida do Audaz Navegante", de Guimarães Rosa, ${ }^{1}$ vai fornecer a oportunidade de se estudar o fazer literário do ficcionista mineiro, bem como viabilizar uma abordagem do papel da fantasia e da relação entre literatura e vida.

Trata-se de um conto dentro de um conto, ou melhor, de duas narrativas que correm interagindo. Uma, conduzida pelo narrador que relata a manhã de um dia de chuva, em que "parecia não acontecer coisa nenhuma", vivida por quatro crianças num sitiozinho mineiro. Três irmãzinhas e um primo: uma delas, Ciganinha, fazia par com o primo Zito, mas os dois estavam “ estremecidos”. Outra, é a história inventada por Brejeirinha, a menor das crianças, sobre um "Audaz Navegante", que vai ganhando consistência ao longo da narrativa, e interferindo no tônus emocional do parzinho de primos.

Começo com a questão do contraponto desse pequeno conto com o "romance grande" que é a épica, a Odisséia de Homero. Importa ver a "reapropriação" que se faz dessa herança clássica, desse "capital cultural"" que é a Odisseia. Flagra-se, para além da atitude parodística no manejo das relações com o clássico, um processo de estilização, estranhamento, carnavalização e transgressão. Isso nos obrigará a por em pauta, minimamente que seja, a questão do cânon literário.

Edward Saïd aponta uma das etimologias da palavra "cânon", que remeteria a um significado musical, o cânon como uma forma contrapontística que emprega inúmeras vozes [...], uma forma, em outras palavras, que expressa movimento, brincadeira, descoberta e, no sentido retórico, invenção. Vistas dessa maneira, as humanidades canônicas, longe de serem uma tábua rígida de regras fixas e monumentos que nos intimidam a partir do passado[...]sempre permanecerão abertas a combinações mutáveis de sentido e significação[...] $]^{3}$.

Vamos então, ver o que rende esse contraponto, para além do procedimento primário de dizer: "Olha, aí há um Navegante, que sofre perigos no mar" - que aludiria ao Navegante prototípico, que é Odisseu; e "Aí há uma moça, que ele ama, e de quem sente saudades, e que ele teme que o esqueça" -que nos remeteria a Penélope. Mais importante que as retomadas do texto clássico, são as modulações, as rupturas, as transgressões do mito; e qual a significação que isso venha a ter.

Falei em "clave minimalista": não apenas o enredo é reduzido aos elementos essenciais da épica original, mas também as personagens são, num certo sentido, miniaturizadas: crianças. No entanto esse "mundo em miniatura" não deixa de abrigar os problemas fundamentais do ser humano: o Destino, a Vida enquanto travessia, a questão da Necessidade X Vontade, o encontro de contrários (coincidentia oppositorum), o Amor. Falando do casalzinho enamorado, diz o narrador: “Eles se disseram coisas grandes em palavras pequenas." (p. 106-7). Tudo é pequeno, diminuto, miniaturizado; e a pequenez (e graça) se concentra na protagonistazinha que é a inventadora de estórias. Efetivamente, assim é descrita Brejeirinha, sentada no caixote de batatas:

Toda cruzadinha, traçadas as pernocas, ocupava-se com a caixa de fósforos. A gente via Brejeirinha: primeiro, os cabelos, compridos, lisos, louro-cobre; e, no meio deles, coisicas diminutas: a carinha não comprida, o perfilzinho agudo, um narizinho que carícia. Aos tantos, não parava, andorinhava [...] (p. 100)

Realmente, tudo são "coisicas diminutas": cruzadinha, carinha, perfilzinho, narizinho... até o verbo está no diminutivo: andorinhava. E o que não é descrição da personagenzinha, o único objeto que nesse trecho é nomeado, é essa espécie de diminutivo de caixa, a saber, "caixa de fósforo".

\footnotetext{
${ }^{1}$ ROSA, Guimarães: "Partida do Audaz Navegante”. Primeiras Estórias. Rio de Janeiro, José Olympio, 12ª .edição, 1981.

${ }^{2}$ Cf. BOURDIEU, P. A economia das trocas simbólicas. São Paulo, Perspectiva, 2007.

${ }^{3}$ SAID, Edward. Humanismo e crítica democrática. São Paulo, Companhia das Letras, 2007. [ed. original: 2004.]
} 
A gente não pode não se lembrar da Emília, d'As Reinações de Narizinho, de Monteiro Lobato, e sua torneirinha de asneiras. Pois bem, Brejeirinha, "um azougue de quieta", que prefere "Antes falar bobagens que calar besteiras", que tem "infimículas inquietações" declara, taxativamente, bem no início do conto: "Eu sei porque é que o ovo se parece com um espeto"! (p. 101).

E essa declaração, que será reiterada nas linhas finais, é o enigma do conto. Efetivamente, esse enigma tem a ver com o amor. Ovo e espeto são elementos polares, em mais de um nível: o espeto, retilíneo e agudo, é a "faca só lâmina" de João Cabral, a figuração do elemento penetrante; o ovo, na sua placidez sem arestas, figura a receptividade incondicional. Ovo e espeto sinalizam um encontro de contrários: orgânico x inorgânico, arredondado (melhor dizendo: ovalado) x pontudo; esfera x seta, masculino x feminino -- remetendo, inescapavelmente, a uma simbologia cada vez mais sexualizada, que remontará até o par primordial de opostos: espermatozóide x óvulo.

Seria interessante transcrever aqui a explicação dada por Guimarães Rosa na sua correspondência com Meyer-Clason, o tradutor alemão, às voltas exatamente com as dificuldades colocadas pelo texto da "Partida do Audaz Navegante":

Há, em português, a expressão "Tão parecidos como um ovo e um espeto", para dizer que duas coisas, ou duas pessoas, são muito diferentes uma da outra. Aqui, Brejeirinha descobre uma profunda verdade metafísica, desmoralizadora da nossa concepção idiota da "realidade estática": as coisas aparentemente mais diferentes, são em verdade, às vezes as mais próximas uma da outra. Veja, a respeito, o próprio título, e o próprio tema da estória. ${ }^{4}$

Então: encontro de contrários, "coincidentia oppositorum" e, como tal, figuração da totalidade, esse enigma não será ao fim propriamente desvendado, mas será por assim dizer efetivado, neste texto que tematiza o amor. E essa é uma preocupação fundamental de Brejeirinha, que diz, ainda no começo do conto:

-- "Eu queria saber o amor..."

-- "Sem saber o amor, a gente pode ler os romances grandes?"

Uma primeira observação que se impõe é que "saber" é da mesma raiz de sabor: a gente "sabe" aquilo que experimenta. E como se diz no português de Portugal, saber é sentir o gosto - por experiência. Brejeirinha, a contadora de histórias, induz a irmã e o primo a "saberem" o amor. A pergunta é: há necessidade de saber o amor, para ler os romances grandes? Mas aqui a coisa se inverte: não são os romances que induzem ao amor? A narrativa inventada por Brejeirinha - remetendo à história de amor entre Odisseu e Penélope, desse "romance grande "que é a épica (matriz do romance de aventuras e do romance de amor) não influenciou o relacionamento de Ciganinha e Zito, o parzinho enamorado? (Voltarei a isso mais adiante.)

Essa espécie de Emília, não do Picapau Amarelo, mas de um sítio à beira do sertão, parecido com o Mutum do Miguelim, outro contador de histórias, inicia uma narrativa - bem à moda daquelas que a boneca de pano aprontava:

Zito, você podia ser o pirata inglório marujo, num navio muito intacto, para longe, lo-õ-onge, no mar, navegante que o nunca-mais, de todos? (p.102).

\footnotetext{
${ }^{4}$ BUSSOLOTTI, Maria Aparecida Faria Marcondes (org.). João Guimarães Rosa: Correspondência com seu tradutor alemão Curt Meyer-Clason (1958-1967). Rio de Janeiro: Nova Fronteira, Academia Brasileira de Letras; Belo Horizonte: Ed. da UFMG, 2003, pp 316-7.
} 
Ao inventar sua história, Brejeirinha coloca os circunstantes como protagonistas da sua fantasia. E as reações dos primos não se fazem esperar: Zito se projeta no herói que vai para longe, e sorri; Ciganinha, diante da perspectiva do "nunca-mais" como pano de fundo desse longe, e da separação implicada, projetase em quem fica, e estremece.

Zito: o nome remete a Joãozito, como João Guimarães Rosa era chamado quando criança. E que, significativamente, na idade adulta, adota o pseudônimo de Viator (Viajante) com o qual inscreve, num concurso de ficção, o que viria a ser seu primeiro livro publicado em 1946, Sagarana.

Mas Brejeirinha, "que gostava, poetista, de importar desses sérios nomes, que lampejam longo clarão no escuro da nossa ignorância", se empolga e prossegue com sua historiazinha:

"O Aldaz Navegante, que foi descobrir os outros lugares valetudinário. Ele foi num navio, também falcatruas. Foi de sozinho. Os lugares eram longe, e o mar. O Aldaz Navegante estava com saudade, antes, da mãe dele, dos irmãos, do pai. Ele não chorava. Ele precisava respectivo de ir. Disse: -- "Vocês vão se esquecer muito de mim?" [...] (p. 102)

$\mathrm{Na}$ sequência, a fala da Brejeirinha, atingindo todos os demais membros do grupinho, registra também o que "a gente" pensa:

"Ele vai descobrir os lugares que nós não vamos nunca descobrir..." [...]

"Ele vai descobrir os lugares, depois ele nunca vai voltar..." (p. 102)

E imediatamente, nessa narrativa inventada na cozinha, "perto do fogo familiar", lugar de contar histórias, repontarão os temas da busca do Longe, da Vita/Via (a vida enquanto caminho), do mar - o mar na sua nudez substantiva; da separação, do risco do esquecimento, da saudade; do imperativo de partir.

Com força já surgiram aqui, nos termos de Dante 5 , "o ardor/que impelia a conhecer o mundo"6, e o elã fáustico que faz o Nauta atirar-se "ao mar aberto e fundo", como diz o Ulisses da Divina Comédia ao Poeta que o encontra no Inferno ${ }^{7}$. Ele precisava respectivo de $i \mathrm{r}$, diz a narrativa de Brejeirinha; sim, navegar é preciso, como veremos mais à frente. Mas antes é o caso de nos debruçarmos sobre esse outro motivo temático da Odisseia que é a saudade, a espera, a nostalgia -- etimologicamente, de nostos (volta) + algia (dor) : a dor do retorno, a saudade. E da parte de quem vai, o medo de ser esquecido.

Já apontei, no início, que essa história de um herói que parte perturba os receptores do relato. É por isso que, com a continuação da narrativa, Ciganinha "se feria em zanga":

--Por que você inventa essa história de de tolice, boba, boba?

-- Porque depois pode ficar bonito, ué! (p. 102)

Nesse diálogo entre as duas irmãzinhas, que vale por uma pequena reflexão sobre a Fantasia e sobre a Literatura x Realidade, há uma ambiguidade. De um lado, "pode ficar bonito" primeiramente porque, ao inventar sua história, Brejeirinha pode deixá-la "bonita”, à sua maneira: ela, efetivamente -- e transgressoramente -- vai alterar o mito: o herói e a moça que ele ama acabam juntos, ela também embarca, vão ambos no navio. De outro lado, a força poderosa da fantasia age sobre a sensibilidade, mobiliza emoções, a literatura "atua" sobre os seres, provoca alterações no concreto. Então, depois “pode ficar bonito" na vida afetiva dos pequenos

\footnotetext{
${ }^{5}$ ALIGHIERI, Dante: Divina Comedia. Trad.Eugenio Mauro. São Paulo, Editora 34, 1998.

${ }^{6}$ Ibidem, "Inferno", XXVI, v. 98.

${ }^{7}$ Ibidem, v. 100.
} 
ouvintes daquela historiazinha inventada - na relação dos primos Zito e Ciganinha, sob o impacto da estória de amor contada pela Brejeirinha, os dois, inicialmente afastados, ficarão, ao longo do conto, "em pé de paz".

Além disso, esse pequeno diálogo abriria outra interessantíssima questão: a da dimensão lúdica da arte, da arte enquanto prolongamento do jogo infantil, como quer Freud em "Escritores Criativos e Devaneios" ". Efetivamente a literatura - arte da palavra - é um prolongamento do faz-de-conta infantil. "Ficção" vem do verbo fingo = fingir. A criança "finge" que a rodela de esterco é um barco, finge (= faz de conta) que o cogumelo que aí medrou é o Aldaz Navegante com seu chapeuzinho, etc, etc. E a própria história do Aldaz Navegante colocada em palavras, com suas aventuras e seu amor, é fruto de um "fingimento", de uma invenção, de mimese, de uma representação da realidade no nível da Fantasia. A gente sabe da necessidade de ficção que habita o coração humano.

Voltemos à Odisséia, origem da ficção literária no Ocidente, matriz do romance de aventuras mesclado a um romance de amor. É a história das aventuras de um herói, tentando voltar para a sua amada, que o espera, enfrentando todos os assédios, inventando seu famoso estratagema para driblar os príncipes aqueus que com ela querem casar-se. Finda a Guerra de Troia, Odisseu demorará 10 anos para conseguir voltar a Ítaca, a ilha em que o amor não fenece jamais. Na sua incontornável intepretação dessa epopéia, Adorno diz que a Odisseia é a viagem metafórica do Homem Ocidental em busca da constituição do eu. E é assim que ele interpreta as aventuras de Odisseu, em luta com as forças míticas e mágicas da Natureza, frente às quais ele se constitui como sujeito, num embate entre a Razão e o poder mítico destrutivo arcaico. Ele se contraporá ao Cíclope, aos gigantes Lestrigões, a Cila e Caribde, aos lotófagos e ao risco da perda da memória, às sereias e sua sedução, etc, etc.; mas ele tem um rumo, um objetivo na sua rota: Ítaca, onde o espera Penélope. Mas antes, terá que enfrentar o Mar e a força destruidora de Poseidon.

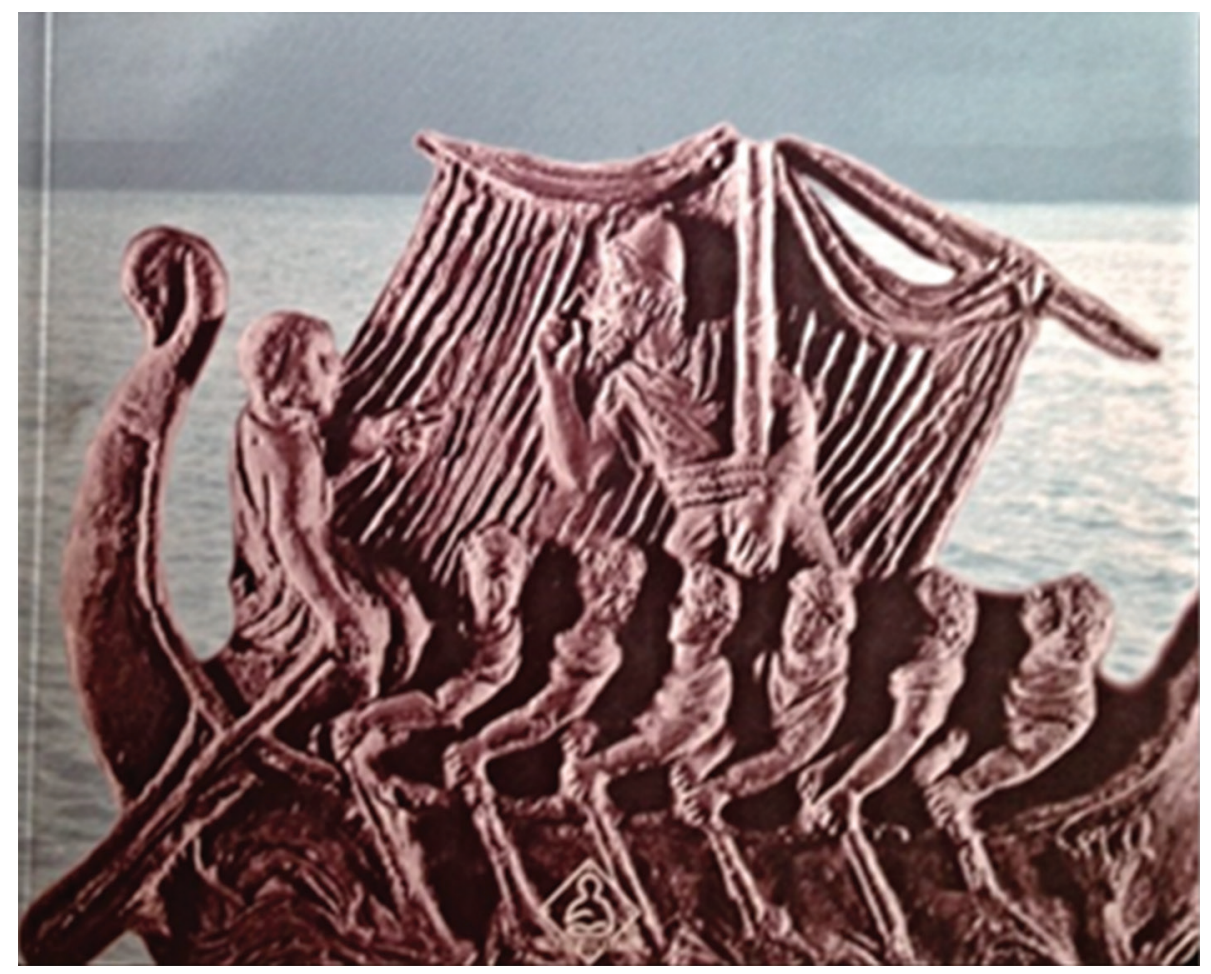

${ }^{8}$ Cf. FREUD, S. "Escritores Criativos e Devaneio". In: Obras Psicológicas Completas. Rio de Janeiro, Imago Editora, vol. IX, 1976. 
O conto de Guimarães Rosa continua, a manhã avança, a chuva amaina, as crianças saem para passear e descobrem, no chão perto do riachinho, que encheu com a chuva, rodelas de esterco cogumeleiro. A fabulação de Brejeirinha continuará, agora com elementos novos:

"O Aldaz Navegante não gostava de mar! Ele tinha assim mesmo de partir? Ele amava uma moça, magra. Mas o mar veio, em vento, e levou o navio dele, com ele dentro, escrutínio. O Aldaz Navegante não podia nada, só o mar, danado de ao redor, preliminar. O Aldaz Navegante se lembrava muito da moça. O amor é original..." -- [...]-- "Envém a tripulação... Então, não. Depois, choveu, choveu. O mar se encheu, o esquema, amestrador... O Aldaz Navegante não tinha caminho para correr e fugir, perante, e o navio espedaçado. O navio perambolava... Ele, com o medo intacto, quase nem tinha tempo de tornar a pensar demais na moça que amava, circunspectos. [...]" -- "A moça estava paralela, lá, longe, sozinha, ficada, inclusive, eles dois estavam nas duas pontinhas da saudade... O amor, isto é... "O Aldaz navegante, o perigo era total, titular... não tinha salvação [...]" (p.105)

É fantasia, mas na atualidade (abril de 2015) isso deve ecoar fundo no coração da gente de uma maneira muito doída - nós que estamos vivendo, em pleno século XXI, a tragédia dos barcos naufragados no Mediterrâneo, carregando migrantes fugindo da África e tentando alcançar a Europa - mais precisamente, Lampedusa. As embarcações são outras, não têm aura mítica, mas as águas são do mesmo Mar Mediterrâneo por onde navegou Odisseu.

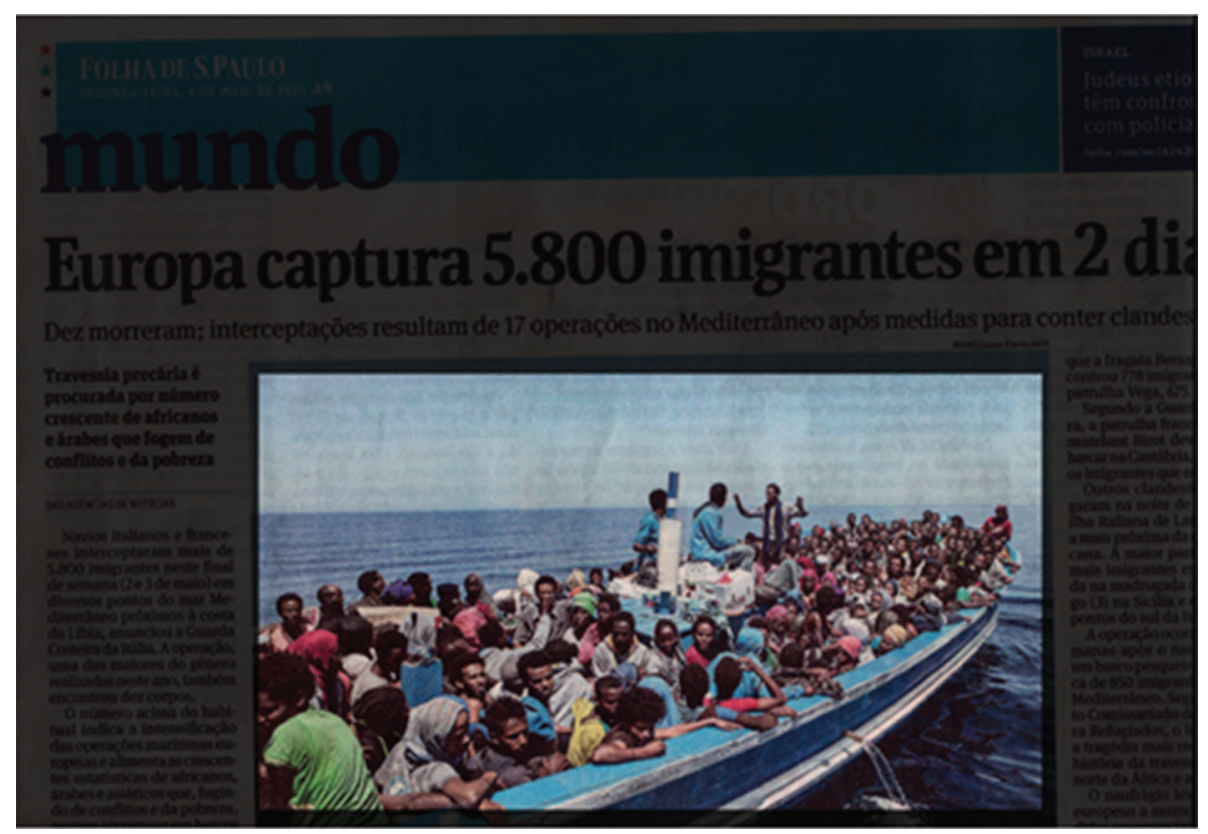

Leio um jornal do dia 22 de abril, ainda ecoando a tragédia da véspera:

850 vítimas. TRAGÉDIA FOI A MAIS MORTAL, SEGUNDO A ONU.

O naufrágio de um barco pesqueiro com 850 imigrantes no domingo (19 de abril de 2015), no mar Mediterrâneo, foi considerada a tragédia mais mortal na história da travessia entre o norte da África e a Europa pelo Alto Comissariado da ONU para refugiados. Até a conclusão desta edição (de 22/04/15), só 28 pessoas haviam sido resgatadas com vida." (Folha de São Paulo, 22 de abril de 2015 - p. A10).

Voltemos para o mundo da ficção. E para o conto do Guimarães Rosa. Vamos retomar o texto anterior da estória inventada por Brejeirinha, selecionando, em meio às aventuras do Navegante, as passagens que configuram a narrativa como um "romance de amor". Como se constata, há uma necessidade em processo, que é reiterada: ele “tinha assim mesmo de partir?”. (Já vimos, páginas atrás, no início da fabulação de Brejeirinha: “Ele precisava 
respectivo de ir".) Mas aqui a afirmação é questionada: é uma interrogação. E o que é importante é que, mesclada à perigosa aventura no mar, a narrativa de Brejeirinha evolui: cria-se um grande espaço para o amor. "Ele amava uma moça, magra." E, em meio aos perigos, "O Aldaz Navegante se lembrava muito da moça".

A reação do parzinho, entre os ouvintes, também evolui: "Ciganinha e Zito sorriram. Riram juntos." Rir juntos é uma forma de comunhão. Evidencia-se uma eficácia da narrativa, a história inventada por Brejeirinha atua nas duas personagens. À medida que avança a fabulação da menininha, continuam a ser registradas as reações de Ciganinha e Zito. Tínhamos já visto os sinais iniciais: Zito sorri, Ciganinha estremece. Agora, "suspiraram-se"; "olham-se nos comovidos não falares"; para eles, o passeio "vira um fato sentimental", etc. A história do Aldaz Navegante intensificará o enamoramento inicial; ao fim do conto eles estão "felizes, alguma outra coisa se agitava neles, confusa-assim rosa-amor-espinhos-saudade." (p. 107). Efetivamente, o amor de Ciganinha e Zito parece tornar-se uma atualização do amor do casal mítico, Penélope e Odisseu.

Insisto na questão fundamental do papel da literatura. Essa atuação da fantasia na sensibilidade, ou melhor, a Literatura como um fator erotizador, tem como exemplo paradigmático, no universo literário ocidental, o episódio de Paolo e Francesca da Rimini, na Divina Comédia. ${ }^{9}$ Trata-se do casal de cunhados que se tornaram amantes e, surpreendidos pelo marido traído, foram mortos como adúlteros, no tempo de Dante, em Rimini. O Poeta os encontrará no Inferno, no Círculo dos luxuriosos. Permanecem, no entanto, juntos.

Registra-se no Canto V do Inferno a cena belíssima em que Dante vê o casal, e lhes pede para que contem como conheceram o desejo de um pelo outro, os "dubbiosi disiri". Francesca se dispõe a contar a "raiz" (a prima radice) daquele amor: um dia eles liam um livro juntos, a história de amor de Lancelote e Guinevra, e no momento em que Lancelote beija Guinevra, Paolo beija Francesca: "la boca mi basciò tutto tremante”. E nesse dia, eles não leram mais livro nenhum. ("Quel giorno più no vi leggemmo avante). Paolo e Francesca "atuaram” aquilo que leram. (Dante, Inferno, Canto V, vs.127 ss -- p. 53).

Vejamos a cena, em tradução de Italo Eugenio Mauro:

"Líamos um dia, nós dois, para recreio de Lancelote e do amor que o prendeu; Éramos sós, e sem qualquer receio.

Vezes essa leitura nos ergueu olhar a olhar, no rosto desmaiado, mas um só ponto foi que nos venceu.

Ao lermos o sorriso desejado ser beijado por tão perfeito amante, este, que nunca seja-me apartado,

tremendo, a boca me beijou no instante. Foi Galeoto o livro, e o seu autor; Nesse dia não o lemos mais adiante"
Noi leggiavamo um giorno per dileto di Lancialotto come amor lo strinse soli eravamo e sanza alcun sospetto.

Per più fiate li occhi ci sospinse quelle lettura, e scolorocci il viso, Ma solo um punto fu quel che ci vinse.

Quando leggemmo il disiato riso esser basciato da cotanto amante, questi, che mai da me no fia diviso,

la bocca mi basciò tutto tremante. Galeoto fu '1 libro e chi lo scrisse; quel giorno più non vi leggemmo avante."

\footnotetext{
${ }^{9}$ ALIGHIERI, op.cit, Canto V, vs.70 a 142.
} 
Voltemos, do casal Francesca e Paolo, de Dante, ao casal Ciganinha e Zito, de Guimarães Rosa. Continua a contadeira de histórias:

"Ele, com o medo, intacto, quase nem tinha tempos de tornar a pensar demais na moça que amava, circunspectos. [...] (p. 105)

"A moça estava paralela, lá, longe, sozinha, ficada, inclusive, eles dois estavam nas duas pontinhas da saudade... O amor, isto é..." (p. 105)

É interessante que na estória de Brejeirinha avultam os elementos de " história de amor" que a Odisséia abriga. Essa dimensão - a de um romance de amor - está significativamente presente na Odisséia, mas em geral não é muito explorada pela crítica. Do lado de Penélope, "lá longe ficada", sim: ela é apresentada como uma espécie de padroeira da fidelidade conjugal, e chora pelo seu marido ausente - além de, astuciosamente, ter urdido a estratégia do manto feito e desfeito, que a reserva para a volta do homem amado. Mas, e do lado de Odisseu? Masculinamente, ou melhor, diríamos -- com o inevitável anacronismo dos critérios da atualidade -- machistamente, ele tem muitos relacionamentos com mulheres - algumas, semi-deusas, como Circe, Calipso; ou mesmo a jovem Nausicaa, com quem tem um flerte. Não é o caso agora - nem teríamos tempo - de relativizar um pouco isso tudo, mostrando o rastreamento que se pode fazer, na Odisséia, da ligação amorosa que Odisseu inequivocamente evidencia com Penélope. Não enquanto estava com suas aventuras no mar, às voltas com ventos, naufrágios, tempestades, ou, quando aportava, lutando com o Cíclope, descendo ao Hades, ou tentando driblar os monstros Cila e Caribde. Nessa situação, assim como o Aldaz de Brejeirinha, "Ele, com o medo, intacto, quase nem tinha tempos de tornar a pensar demais na moça que amava" - Mas, por exemplo, ao fim de uma estadia prolongada com Calipso, Odisseu também chora de saudades de casa. $\mathrm{Na}$ realidade, ele e Penélope, também, "eles dois estavam nas duas pontinhas da saudade". Mas eu queria atrair a atenção para apenas uma cena: quando Odisseu volta e o casal mítico se reúne, cada um contando ao outro o que se passou nessa longa ausência, eles à noite vão para a cama, ou melhor, para o famoso leito conjugal, inamovível (construído pelo próprio Odisseu, num tronco de oliveira solidamente enraizado no centro do Palácio de Ítaca): pois bem, por iniciativa de Atena, a Aurora atrasa, a fim de que a noite se prolongasse, para que eles pudessem saciar a grande saudade dos seus abraços. O amor de Odisseu e Penélope tem uma dimensão cósmica, belíssima - interfere na chegada do sol, atrasa o romper do dia!

Em todo o caso, amor e aventura, alimentando a fantasia humana, sempre.

Vamos, agora, de Guimarães Rosa, recuar a Fernando Pessoa, que colocou em circulação a famosa frase "Navegar é preciso, viver não é preciso". Pessoa a atribui a "Navegadores Antigos" e, tratando-se de algo vindo do Poeta de Mensagem, seríamos tentados a localizar esse lema na época das Grandes Navegações de Portugal. Mas na realidade, ele é de uma época bem anterior: essa frase está registrada em Plutarco, na biografia do General Pompeu, do século I aC. Responsável pelos navios romanos que tinham a missão de levarem suprimentos das províncias, sobretudo o trigo, à cidade de Roma, em meio aos perigos da navegação na Antiguidade, Pompeu teria exortado seus soldados pronunciando a famosa frase: Navigare Necesse, Vivere non Necesse. (Aprox. 70 a.C). 
Fernando Pessoa se apropria desse lema, toma-o para si, tira-o do contexto das Grandes Navegações e o reinterpreta, redirecionando-o à esfera da criação poética. ${ }^{10}$

Pois bem, Caetano Veloso pega o mote de Fernando Pessoa e compõe a belíssima canção "Os Argonautas" 11 - que são navegantes de um tempo mítico muito anterior aos tempos (históricos) do General Pompeu. No entanto, essa frase entrou para a lenda.

Eis a canção:

\section{O barco}

Meu coração não aguenta

Tanta tormenta, alegria

Meu coração não contenta

O dia

O marco

Meu coração

O porto

Não

Navegar é preciso

Viver não é preciso

\section{O barco}

Noite no teu tão bonito

Sorriso solto, perdido

Horizonte e madrugada

O riso

$O$ arco

Da madrugada

O porto

Nada

Navegar é preciso

Viver não é preciso

${ }^{10}$ Escreve Fernando Pessoa:

"Navegadores antigos tinham uma frase gloriosa: 'Navegar é preciso, viver não é preciso'.

Quero pra mim o espírito desta frase, transformada a forma para a casar com o que eu sou: Viver não é necessário; o que é necessário é criar.

Não conto gozar a minha vida; nem em gozá-la penso. Só quero torná-la grande, ainda que para isso tenha de ser o meu corpo e a minha alma a lenha desse fogo.

Só quero torná-la de toda a humanidade; ainda que para isso tenha de a perder como minha.

Cada vez mais assim penso. Cada vez mais ponho na essência anímica do meu sangue o propósito impessoal de engrandecer a pátria e contribuir para a evolução da humanidade.

É a forma que em mim tomou o misticismo da nossa raça."

(Nota solta não assinada publicada em: "Introdução geral". In: PESSOA, Fernando: Obra poética. Rio de Janeiro, Aguilar, 1965, p. 15)

${ }^{11}$ VELOSO, Caetano. Os Argonautas. 1968. 
O barco

O automóvel brilhante

O trilho solto, barulho

Do meu dente em tua veia

O sangue

O charco

Barulho lento

O porto

Silêncio

Navegar é preciso

Viver não é preciso

Navegar é preciso

Viver não é preciso

\section{Navegar é preciso Viver}

Não vou fazer análise, mas quero apenas apontar que nessa canção que fala de navegar, porto, marco e coração que não aguenta (não se sabe bem o que, se tormenta ou alegria), sorriso, veia, etc, há também um duplo registro, de aventura e de amor. Retornarei a essa canção mais adiante.

Voltemos ao fio condutor, que é o conto "Partida do Aldaz Navegante" acompanhado em sua sequência rigorosamente cronológica. Num determinado momento do passeio das crianças, perto do riachinho que enchera com a chuva, de repente algo da "realidade" se impõe: as crianças descobrem, no limo, a ponto de ser atingida pela enchente,

... a coisa vacum, atamanhada, embatumada, semi-ressequida, obra pastoril no chão de limugem, e às pontas dos capins-chato, deixado. Sobre sua eminência, crescera um cogumelo de haste fina e flexuosa, muito longa: o chapeuzinho branco, lá em cima, petulante se bamboleava. (p.105-6)

Uma das crianças aponta o achado, e nomeia; “-E - olha o seu "Aldaz Navegante”, ali. É aquele..."

As crianças transformam uma rodela de esterco de boi em navio, e o cogumelo que medrou desse estrume, com seu chapeuzinho, no Navegante audaz. Estranhamento: algo que é muito comum a G. Rosa no seu vocabulário, na sua sintaxe, nos seus enredos, com o objetivo da propalada desautomatização do poético, da ruptura de expectativas, o despertar da percepção adormecida dos leitores. Do mesmo jeito que Guimarães Rosa recupera o "Cântico dos Cânticos” em Dãolalalão, transformando o Amado e a Amada, respectivamente, em um ex-matador de jagunçoes e uma ex-prostituta, aqui também ele transforma o grande herói navegante arquetípico e seu navio em uma rodela de esterco bovino, onde cresceu um cogumelo. A ilustração de Luís Jardim na capa de Primeiras Estórias ${ }^{12}$, da Livraria José Olympio Editora, figura o "bovino", ladeado por uma caravela portuguesa à esquerda, e por um barco a remo, da Antiguidade, à direita.

\footnotetext{
${ }^{12}$ ROSA, op.cit.
} 


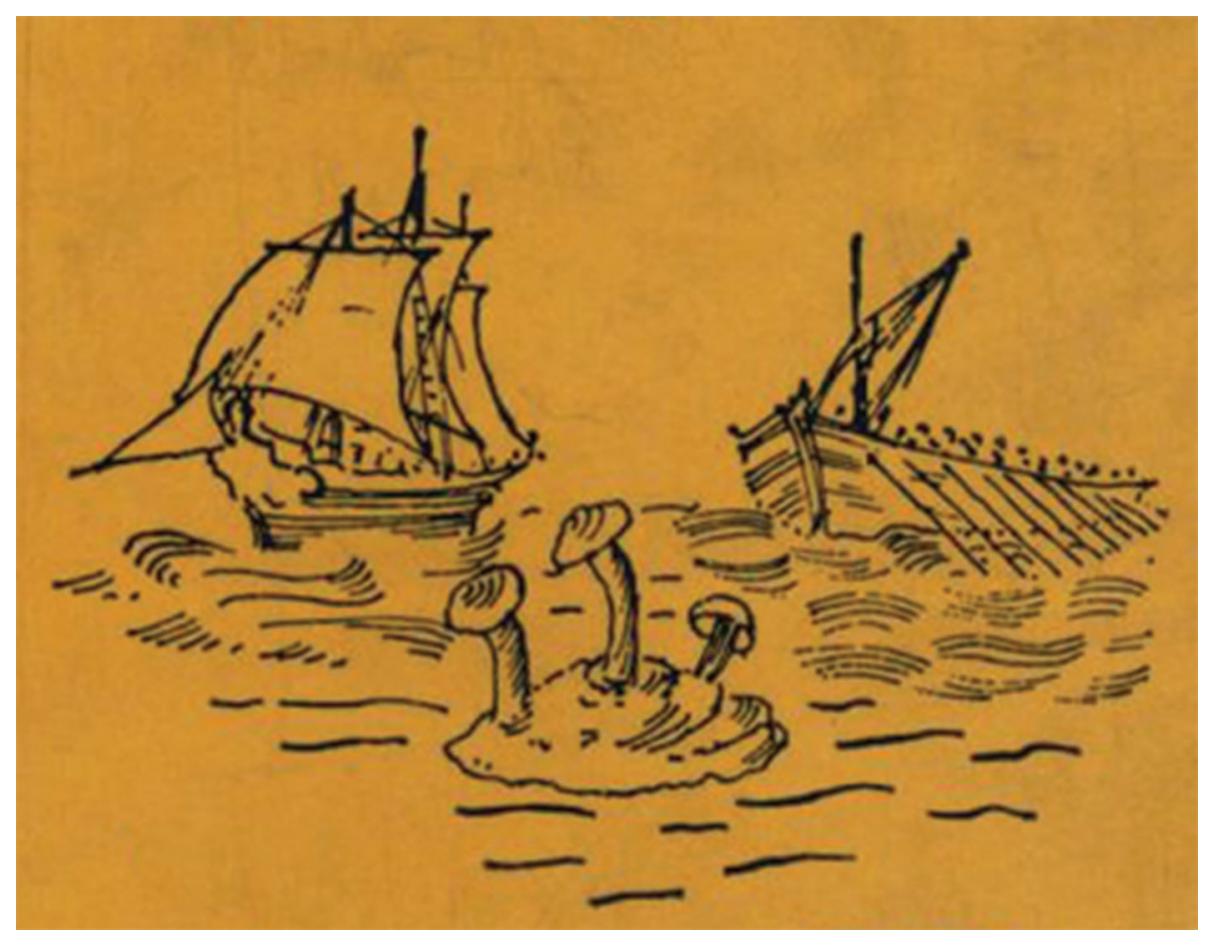

Efetivamente, a Odisseia, nas palavras do crítico Edward Saïd, que eu citei, no início, sobre o cânon, seria um desses "monumentos que nos intimidam a partir do passado", mas aqui ele é carnavalizado. O termo é de Bakhtin, em estudo sobre a obra de Rabelais. Efetivamente, o navio do herói figurado como esterco de boi é um agudo exemplo de carnavalização -- esse processo paródico da cultura popular, vigente na Idade Média e no Renascimento, que se opunha à cultura oficial de tom sério (religioso ou feudal). Os críticos sempre costumavam assinalar a predominância, em Rabelais, do que Bakhtin chama de princípio da vida material e corporal, de um "fisiologismo grosseiro", mas que adquiriria um caráter cósmico e universal. Para o crítico russo, o "rebaixamento", que é uma característica do realismo grotesco, mostra uma ambivalência. Esse rebaixamento seria uma "transferência ao plano material e corporal, o da terra e do corpo na sua indissolúvel unidade, de tudo que é elevado, espiritual, ideal e abstrato". ${ }^{13}$ Bakhtin aponta em Rabelais a importância significativa dos excrementos (num único parágrafo por ele apontado, por exemplo, são citados quinze nomes de excrementos, dos eruditos aos de mais baixo calão). Com essa chave de leitura, poderíamos ver no estrume de boi que figura o "Aldaz Navegante" e seu navio, essa transferência de valores:

O caráter ambivalente dos excrementos, sua ligação com a ressurreição e com a renovação e o seu papel particular na vitória sobre o medo aparece aqui muito claramente, é a matéria alegre. Nas figuras escatológicas mais antigas, [...] os excrementos estão ligados à virilidade e fecundidade. Por outro lado, os excrementos têm o valor de alguma coisa a meio caminho entre a terra e o corpo, alguma coisa que os une. São assim algo intermediário entre o corpo vivo e o corpo morto em decomposição, que se transforma em terra boa, em adubo; o corpo dá os excrementos à terra durante a vida; os excrementos fecundam a terra, como o corpo do morto. ${ }^{14}$

Depois de apontado o Aldaz Navegante e seu barco no esterco, Brejeirinha vai continuar sua história, refazendo-a:

\footnotetext{
${ }^{13}$ Ibidem, p. 17.

${ }^{14}$ Ibidem, p.151.
} 
Então, pronto. Vou tornar a começar. O Aldaz Navegante, ele amava a moça, recomeçado. Pronto. E, de repente, se envergonhou de ter medo, deu um valor, desassustado, Deu um pulo onipotente.... Agarrou, de longe, a moça em seus abraços... Então, pronto. O mar foi que se aparvolhou-se. Arres! O Aldaz Navegante, pronto. Agora, acabou-se, mesmo: eu escrevi - "Fim”! (p.106)

Efetivamente, Brejeirinha inventa porque "pode ficar bonito". Mas como ela é uma criança, não tem compromissos de ficcionista, depois desse "Fim", que ela mesma apõe, vai "recontar a verdadeira estória". E é assim que finalizará sua narrativa:

Agora, eu sei. O Aldaz Navegante não foi sozinho; pronto! Mas ele embarcou com a moça que ele amavam-se, entraram no navio, estricto. E pronto. O mar foi indo com eles, estético. Eles iam sem sozinhos, no navio, que ficando cada vez mais bonito, mais bonito, o navio.... pronto: e virou vagalumes... (p. 107)

Brejeirinha transgride a narrativa mítica: ela faz embarcar a mulher no navio. E o mar, que na primeira versão, era "estático", fica "estético". No entanto, esse fim da história, ou melhor, um fim nessa mesma linha era o que o Caetano Veloso também tinha aventado na canção "Argonautas”. O último refrão, ou melhor, os últimos versos do refrão da Canção "Argonautas”, são assim cantados:

Navegar é preciso

Viver não é preciso

Navegar é preciso Viver

Caetano Veloso "resolve" a terrível equação:

\section{NAVEGAR É PRECISO VIVER}

Nessa mesma linha, fiel à narrativa de Brejeirinha, vai a ilustração de Luís Jardim para o Conto XVI, "Partida do Audaz Navegante", no inusitado "Índice Ilustrado" de Primeiras Estórias, da Editora José Olympio".

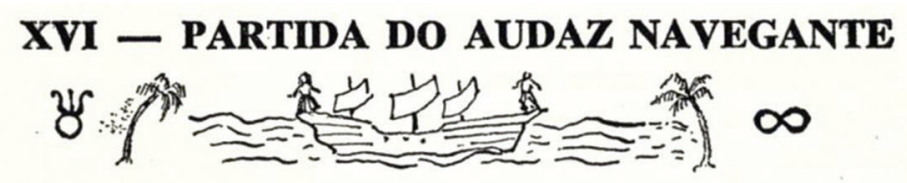

Aí se vê ao centro um navio com três velas, um homem à direita, uma mulher à esquerda. Pela lógica da tradição, ou melhor, pela lógica do mito, a mulher jamais embarcaria, mas isso é "transgredido" na história de Brejeirinha.

Sim, como reitera a pequena ficcionista, nas linhas finais do conto, "o ovo só se parece, mesmo, é com o espeto."

Recebido em: 05/06/2015

Aprovado em: 02/07/2015

${ }^{15}$ ROSA, op.cit. (capa e ínndice ilustrado por Luís Jardim). 